\title{
KETIMPANGAN DISTRIBUSI PENERIMAAN RUMAHTANGGA PETANI LADA HITAM DI DESA TEMDAK KECAMATAN SEBERANG MUSI KABUPATEN KEPAHIANG PROVINSI BENGKULU
}

\author{
${ }^{1}$ Dewi Ritonga, ${ }^{2}$ Nyayu Neti Arianti*, ${ }^{3}$ Redy Badrudin \\ 1,2Jurusan Sosial Ekonomi Pertanian FP Universitas Bengkulu, Bengkulu, Indonesia \\ *)email korespondensi: nnarianti@unib.ac.id
}

\begin{abstract}
ABSTRAK
Ketimpangan distribusi ekonomi di pedesaan masih menjadi perhatian selain tingkat kemiskinan. Pemerataan kesejahteraan di antara rumahtangga petani menjadi tolok ukur kemajuan di sektor pertanian. Penelitian ini bertujuan untuk menganalisis ketimpangan distribusi penerimaan rumahtangga petani lada hitam di Desa Temdak Kecamatan Seberang Musi Kabupaten Kepahiang. Jumlah responden sebanyak 57 orang diambil dengan metode Slovin. Ada dua metode yang digunakan untuk menentukan ketimpangan distribusi penerimaan, yakni Gini Ratio (GR) dan Kriteria Ketimpangan Bank Dunia. Analisis ketimpangan penerimaan dilakukan pada setiap sumber penerimaan. Tingkat ketimpangan distribusi penerimaan rumahtangga petani lada hitam di Desa Temdak berdasarkan Gini Ratio dan kriteria Bank Dunia menunjukkan hasil yang senada. Penerimaan usahatani lada hitam dan total penerimaan rumahtangga terkategori ketimpangan rendah dengan nilai GR masingmasing 0,351 dan 0,350 serta berdasarkan kriteria Bank Dunia masing-masing 19,26\% dan $18,04 \%$. Penerimaan usahatani non lada hitam termasuk dalam kategori ketimpangan sedang dengan nilai GR sebesar 0,398 dan 15,22\% menurut kriteria Bank Dunia. Sementara ketimpangan penerimaan non pertanian antar rumahtangga petani lada hitam tergolong ketimpangan tinggi yang ditunjukkan oleh nilai GR 0,705 dan $0,00 \%$ berdasarkan kriteria Bank Dunia.
\end{abstract}

Kata kunci: lada hitam, distribusi penerimaan, ketimpangan

\section{ABSTRACT}

Inequality of economic distribution in rural areas is still a concern besides the poverty level. Equitable welfare among farm households is a benchmark of progress in the agricultural sector. This study aims to analyze the distribution of household income of black pepper farmers in Temdak Village, Seberang Musi District, Kepahiang District. The number of respondents was 57 taken by the Slovin method. There are two methods used to determine the inequality of revenue distribution, namely the Gini Ratio $(G R)$ and the World Bank Inequality Criteria. An income inequality analysis is performed at each source of revenue. The level of inequality in the distribution of household income based on the Gini Ratio and World Bank criteria shows similar results. Black pepper farming receipts and total household income are categorized as low inequality with GR values of 0.351 and 0.350 respectively and based on World Bank criteria respectively $19.26 \%$ and $18.04 \%$. Income distribution of non-black pepper farming is moderate inequality with GR values of 0.398 and $15.22 \%$ according to World Bank criteria. While the income distribution of non-agricultural income among households is classified as high inequality as indicated by GR values of 0.705 and $0.00 \%$ based on World Bank criteria.

Keywords : black pepper, income distribution, inequality 


\section{PENDAHULUAN}

Tingkat kemiskinan dan kesenjangan atau ketimpangan merupakan indikator kesejahteraan rakyat suatu negara atau wilayah. Jika tingkat kemiskinan dan ketimpangan rendah, maka negara atau wilayah tersebut bisa dikatakan dalam kondisi sejahtera. Selama hampir dua dekade, tingkat kemiskinan di Indonesia mencapai titik terendah pada 2017, yakni sebesar 10,12 persen. Persentase penduduk miskin Indonesia berkurang sebesar $0,58 \%$ pada bulan September 2017. Selain tingkat kemiskinan yang semakin menurun, ketimpangan pada 2017 juga semakin membaik, yang ditandai dengan menurunnya angka Gini Rasio sebesar 0,391 persen. Kemajuan-kemajuan ini diperkirakan disebabkan antara lain oleh kebijakan pertanian dan pengembangan ekonomi produktif melalui reforma agraria dan peningkatan produktivitas di sektor pertanian (KementerianPPN/Bappenas Republik Indonesia, 2017).

Menurut Sa'diyah dan Irham (2016) sektor pertanian terbukti berperan lebih besar dalam mengurangi ketimpangan pendapatan masyarakat. Sementara Yasrizal dan Hasan (2016) menyatakan sebaliknya, yakni jika pertumbuhan tingkat PDRB sektor pertanian yang semakin tinggi maka kesenjangan distribusi pendapatan akan semakin melebar. Artinya bahwa pertumbuhan PDRB sektor pertanian berpengaruh positif terhadap distribusi pendapatan.

Subsektor perkebunan rakyat sebagai salah satu subsektor pertanian menjadi andalan sumber mata pencaharian sebagian besar penduduk perdesaan. Kepemilikan akses modal dan input menyebabkan terjadi perbedaan pendapatan di antara petani perkebunan di perdesaan. Komoditi-komoditi seperti kelapa sawit, karet, kakao dan lada menjadi pilihan.

Lada (Pipper nigrum L) merupakan salah satu komoditas perkebunan yang telah memberikan kontribusi nyata sebagai sumber devisa, penyedia lapangan kerja dan sumber pendapatan petani. Dalam sejarah perdagangan rempah-rempah, lada dikenal sebagai The King of Spices atau rajanya rempah-rempah. Baik karena nilainya yang tinggi dan volume perdagangannya sangat besar dibandingkan rempah-rempah lainnya, juga merupakan salah satu komoditas rempah-rempah tertua yang diperdagangkan (Risfaheri, 2012).

Kecamatan Seberang Musi Kabupaten Kepahiang merupakan salah satu wilayah pengembangan komoditi 
perkebunan lada yang merupakan komoditas subsektor perkebunan potensial. Kecamatan Seberang Musi adalah penghasil lada terbesar dan jika dioptimalkan bisa menjadi penghasil lada terbaik di Provinsi Bengkulu (https://kepahiang.progres.id, 2016). Sebuah tulisan juga menyatakan bahwa Kecamatan Seberang Musi adalah penghasil komoditi kopi dan lada terbesar di Kabupaten Kepahiang bahkan Provinsi Bengkulu. Desa Temdak menjadi sentra produksi lada di Kecamatan Seberang Musi. Jumlah petani di Desa Temdak adalah 216 orang, 134 di antaranya mengusahakan tanaman lada sebagai mata pencaharian utama untuk memenuhi kebutuhan rumahtangga.

Atas dasar pemikiran sebelumnya, bahwa ada perbedaan pendapat tentang perang sektor pertanian dalam pertanian mengurangi ketimpangan, maka dalam penelitian ini akan menyoroti rumahtangga petani lada yang menjadikan perkebunan lada sebagai mata pencaharian andalan. Produk yang dihasilkan berupa lada hitam.

Permasalahan yang sering timbul adalah apabila produksi lada hitam yang sedikit dan harga produk lada hitam yang rendah, maka penerimaan rumahtangga petani menjadi rendah. Musim panen buah lada adalah dari bulan Mei sampai
September, sehingga pada bulan-bulan lain (Oktober sampai April) jumlah produksi lada rendah karena hanya buah-buah sela antar musim. Sementara kebutuhan rumahtangga harus selalu dipenuhi. Akibatnya rumahtangga petani lada hitam mencari sumber penerimaan lain untuk memenuhi kebutuhan hidup rumahtangganya yang semakin meningkat dari waktu ke waktu, sehingga sumber pendapatan antar rumahtangga petani lada hitam menjadi beragam. Berbagai jenis kegiatan dalam rangka untuk memenuhi kebutuhan dilakukan oleh petani, baik di sektor pertanian, seperti melakukan budidaya tanaman kopi dan tanaman palawija, maupun kegiatan di luar sektor pertanian seperti berdagang, menjadi tukang ojek, dan lain-lain. Berdasarkan permasalahan tersebut, maka penelitian ini bertujuan untuk menganalisis distribusi penerimaan antar rumahtangga petani lada hitam di DesaTemdak.

\section{METODE PENELITIAN}

Penelitian ini dilaksanakan di Desa Temdak Kecamatan Seberang Musi Kabupaten Kepahiang Provinsi Bengkulu. Penentuan lokasi penelitian dipilih secara sengaja dengan pertimbangan bahwa Desa Temdak adalah salah satu desa yang sebagian besar masyarakatnya mengusahakan tanaman lada sebagai 
sumber utama pendapatan rumahtangga. Penelitian dilakukan pada bulan Januari sampai Febuari 2018.

Jumlah rumahtangga petani lada hitam di Desa Temdak adalah sebanyak 134 rumahtangga. Metode penentuan jumlah responden yang digunakan dalam penelitian ini adalah metode Slovin, yang dihitung dengan rumus :

$$
n=\frac{N}{1+N e^{2}}
$$

Dimana, $\mathrm{N}$ adalah jumlah populasi, $\mathrm{n}$ adalah jumlah responden dan e adalah batas toleransi kesalahan (taraf kepercayaan 10\%). Maka jumlah responden yang diambil adalah:

$$
\begin{aligned}
& \mathrm{n}=\frac{N}{1+N e^{2}} \\
& \mathrm{n}=\frac{134}{1+134(0,10)^{2}} \\
& \mathrm{n}=\frac{134}{2,34} \\
& \mathrm{n}=57
\end{aligned}
$$

Sehingga jumlah responden penelitian ini adalah 57 orang.

Analisis distribusi penerimaan rumahtangga didahului dengan mengidentfikasi struktur penerimaan rumahtangga petani lada hitam, dengan cara mengidentifikasi sumber penerimaan rumahtangga, yakni dari pertanian (usahatani lada hitam dan usahatani non lada hitam) dan non pertanian. Total penerimaan rumahtangga petani lada hitam dalam satuan $\mathrm{Rp} / \mathrm{bulan}$ dihitung dengan rumus:

$$
\begin{aligned}
& R_{R T}=\sum_{i=1}^{m} R_{P}+\sum_{p=1}^{o} R_{N P} \\
& R_{R T}=\left(\left(R_{L}\right)+\sum_{j=1}^{n}\left(R_{N L}\right)\right)+\sum_{p=1}^{o}\left(R_{N P}\right)
\end{aligned}
$$

Dimana, $\mathrm{R}_{\mathrm{RT}}$ adalah total penerimaan rumahtangga petani lada hitam, $\mathrm{R}_{\mathrm{P}}$ adalah penerimaan dari usaha pertanian, $R_{L}$ adalah penerimaan dari usahatani lada hitam, $\mathrm{R}_{\mathrm{NL}}$ adalah penerimaan dari usahatani non lada hitam, $\mathrm{R}_{\mathrm{NP}}$ adalah penerimaan dari usaha non pertanian, i adalah jenis-jenis usaha pertanian, $\mathrm{j}$ adalah jenis-jenis usahatani selain lada hitam, dan $\mathrm{p}$ adalah jenis-jenis sumber penerimaan non pertanian. Lalu dihitung persentase masing-masing sumber penerimaan terhadap total penerimaan rumahtangga.

Analisis distribusi penerimaan rumahtangga petani menggunakan metode Gini Ratio (GR) dan metode Bank Dunia.

a. Gini Ratio (GR)

Nilai GR sebagai ukuran pemerataan penerimaan mempunyai selang nilai antara 0 dan 1 . Nilai GR mendekati 0 menunjukkan ketimpangan distribusi yang rendah atau distribusi penerimaan merata di antara rumahtangga. Jika nilai GR mendekati 1,0 artinya ketimpangan distribusi penerimaan tinggi atau distribusi penerimaan tidak merata (Todaro dan Smith, 2003).

$$
G R=1-\sum_{i=0}^{k} f i(Y i+Y i-1)
$$


Dimana, fi adalah proporsi atau persentase jumlah rumahtangga petani lada hitam, Y adalah proporsi atau persentase penerimaan kumulatif dari jumlah penerimaan rumahtangga petani lada hitam, i adalah penerimaan rumahtangga petani sampai kelas ke-i, dan $\mathrm{k}$ adalah jumlah kelas. Selanjutnya ketimpangan dikategorikan berdasarkan nilai GR dapat dilihat pada Tabel 1.

Tabel 1. Kategori Ketimpangan Berdasarkan Nilai Gini Ratio

\begin{tabular}{cc}
\hline Nilai Gini Ratio & $\begin{array}{c}\text { Kategori } \\
\text { Ketimpangan }\end{array}$ \\
\hline $0,00-0,35$ & Rendah \\
$0,36-0,50$ & Sedang \\
$0,51-1,00$ & Tinggi \\
\hline
\end{tabular}

Sumber : Todaro dan Smith, 2003

b. Bank Dunia

$$
\text { Kuncoro (1997) menyatakan }
$$

kriteria ketimpangan distribusi penerimaan yang ditentukan Bank Dunia ini mengukur tingkat pemerataan penerimaan dengan melihat persentase penerimaan yang diterima oleh $40 \%$ penduduk berpenerimaan terendah.

Tabel 2. Kategori Ketimpangan menurut Bank Dunia

\begin{tabular}{cc}
\hline $\begin{array}{c}\text { Persentase penerimaan } \\
\text { yang diterima oleh } \\
\mathbf{4 0 \%} \text { penduduk } \\
\text { berpenerimaan } \\
\text { terendah }\end{array}$ & $\begin{array}{c}\text { Kategori } \\
\text { Ketimpangan }\end{array}$ \\
\hline$>17$ & \\
$12-17$ & Rendah \\
$<12$ & Sedang \\
\hline
\end{tabular}

Sumber: BPS, 2018

Distribusi penerimaan di antara rumahtangga petani juga akan digambarkan dengan scatter diagram untuk lebih memperjelas posisi sebaran data-data penerimaan yang diperoleh.

\section{HASIL DAN PEMBAHASAN}

\section{Struktur Penerimaan Rumahtangga Petani Lada Hitam}

Penerimaan rumahtanggadalah total penerimaan yang diperoleh dari semua kegiatan ekonomi sehari-hari dalam satu bulan. Struktur penerimaan rumahtangga petani lada hitam disajikan dalam Tabel 3 dan Gambar 1. Data pada Tabel 3 dan Gambar 1 tersebut menunjukkan bahwa usaha perkebunan lada hitam menjadi sumber penerimaan yang dominan.

Tabel 3. Struktur Penerimaan Rumahtangga Petani Lada Hitam di Desa Temdak 


\section{Sumber Penerimaan}

1. Pertanian

a. Usahatani Lada Hitam

b. Non Usahatani Lada Hitam

2. Non Pertanian

Total Penerimaan Rumahtangga (1+2)

Sumber : Data Primer Diolah, 2018

Penerimaan dari pertanian sebesar 73,65 \% dari total penerimaan rumahtangga. Hal ini menunjukkan bahwa petani lada hitam memang mengandalkan usaha pertanian sebagai sumber utama penerimaan rumahtangga. Penerimaan pertanian ini terdiri dari penerimaan dari usahatani lada hitam dan dari usahatani komoditi pertanian selain lada hitam. Penerimaan dari usahatani lada hitam berkontribusi sebesar 48,19\% terhadap total penerimaan rumahtangga, sementara selebihnya diperoleh dari kegiatan usahatani komoditas lain.

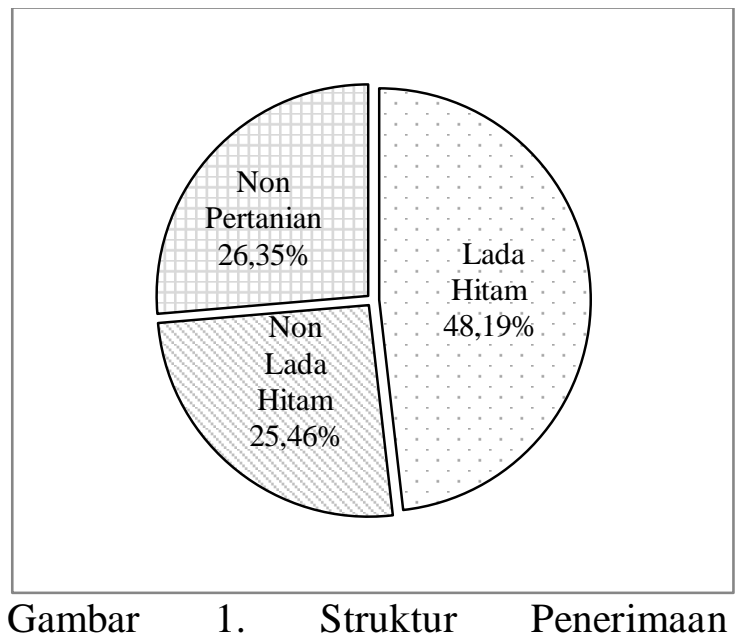

Rumahtangga Petani Lada Hitam di Desa Temdak

Rata-rata penerimaan usahatani selain dari lada hitam yaitu dari usahatani kopi, padi sawah, cabe, pala, kelapa sawit dan beternak kambing adalah sebesar $\mathrm{Rp}$ 598.617/bulan (25,46 \%). Usahatani selain lada hitam dilakukan untuk menjadi cadangan atau tambahan sumber penerimaan rumahtangga. Sebagai tanaman-tanaman seperti kopi, cabe dan pala ditanam oleh tumpang sari dengan tanaman lada. Menurut Lithourgidis et al (2011) tumpangsari adalah praktik pertanian polikultur yang mengusahakan dua atau lebih tanaman di lahan dan waktu yang sama. Tujuannya adalah untuk memanfaatkan sumber daya pertumbuhan dan tenaga kerja yang tersedia. Manfaat yang paling umum dirasakan adalah produktifitas lahan yang lebih tinggi dibandingkan pengusahaan tanaman monokultur. Tumpangsari menjadi solusi apabila terjadi kegagalan panen, 
penurunan produktifitas tanaman atau terhadap harga yang tidak stabil. Petani lada hitam di Desa Temdak melakukan tumpangsari dengan tanaman lain karena harga lada hitam sering mengalami penurunan.

Upaya lain yang dilakukan petani lada hitam untuk memenuhi kebutuhan rumahtanggadalah dengan berusaha di luar sektor pertanian, yakni bekerja sebagai buruh, tukang kayu, pedagang, pegawai honor atau Pegawai Negeri Sipil. Ratarata penerimaan rumahtangga yang dari kegiatan non pertanian adalah $\mathrm{Rp}$ 619.474/bulan $(26,35 \%)$.

Beragamnya sumber penerimaan rumahtangga petani lada hitam tidak lain karena tuntutan kebutuhan untuk mempertahankan hidup serta untuk

Tabel 4. Ketimpangan Penerimaan Rumahtangga Petani Lada Hitam pada Berbagai Sumber Penerimaan berdasarkan Nilai Gini Ratio (GR)

\begin{tabular}{lcc}
\hline \multicolumn{1}{c}{ Sumber Penerimaan } & Gini Ratio $(\mathbf{G R})$ & Kategori Ketimpangan \\
\hline 1. Usahatani Lada Hitam & 0,35 & Rendah \\
2. Usahatani Non Lada Hitam & 0,40 & Sedang \\
3. Usaha Non Pertanian & 0,70 & Tinggi \\
4. Total Penerimaan Rumahtangga & 0,35 & Rendah \\
\hline
\end{tabular}

Sumber : Data Primer Diolah, 2018

\section{Bank Dunia}

Hasil analisis distribusi penerimaan rumahtangga petani lada hitam di Desa Temdak berdasarkan kriteria ketimpangan Bank Dunia dapat dilihat pada Tabel 5. Hasil penelitian menunjukkan ketimpangan distribusi penerimaan rumahtangga dari masing-masing sumber

Jurnal AGRIBIS Vol XIII. No. 2 Juli 2020 Hal 1514-1528

meningkatkan kesejahteraan rumahtangga. Oleh karena itu rumahtangga petani lada hitam mengusahakan perolehan penerimaan lebih dari satu sumber.

\section{Ketimpangan Distribusi Penerimaan Rumahtangga \\ Gini Ratio (GR)}

Ketimpangan distribusi penerimaan rumahtangga dianalisis berdasarkan jenis sumber penerimaan, yakni penerimaan usahatani lada hitam, usahatani non lada hitam, non pertanian dan total penerimaan. Nilai GR masing-masing penerimaan dari berbagai sumber dapat dilihat pada Tabel 4. Demikian pula dengan hasil analisis ketimpangan menurut Bank Dunia, penerimaan usahatani lada hitam dan total penerimaan termasuk dalam kategori rendah (Tabel 5). 
penerimaan berdasarkan nilai GR sama dengan hasil analisis ketimpangan berdasarkan Bank Dunia, yang selanjutnya dijelaskan menurut sumber-sumber penerimaan rumahtangga.

Tabel 5. Ketimpangan Distribusi Penerimaan Rumahtangga Petani Lada Hitam pada Berbagai Sumber Penerimaan berdasarkan Kriteria Bank Dunia

\begin{tabular}{lcc}
\hline \multicolumn{1}{c}{ Sumber Penerimaan } & Persentase $^{*)}$ & Kategori Ketimpangan \\
\hline 1. Usahatani Lada Hitam & 19,26 & Rendah \\
2. Usahatani Non Lada Hitam & 15,22 & Sedang \\
3. Usaha Non Pertanian & 0,00 & Tinggi \\
4. Total Penerimaan Rumahtangga & 18,04 & Rendah \\
\hline
\end{tabular}

Keterangan : ${ }^{*}$ persentase yang diterima oleh $40 \%$ kelompok rumahtangga berpenerimaan terendah

Sumber : Data Primer Diolah (2018)

\section{Penerimaan Usahatani Lada Hitam}

Penerimaan dari usahatani lada hitam relatif merata (ketimpangan rendah) di antara rumahtangga petani. Hal ini ditunjukkan oleh nilai GR sebesar 0,35 dan menurut kriteria Bank Dunia, persentase yang diterima oleh $40 \%$ kelompok rumahtanggaberpenerimaan terendah adalah 19,26\%. Sebaran data pada Gambar 2 juga menunjukkan bahwa penerimaan dari usahatani lada hitam relatif merata di sekitar garis rata-rata.

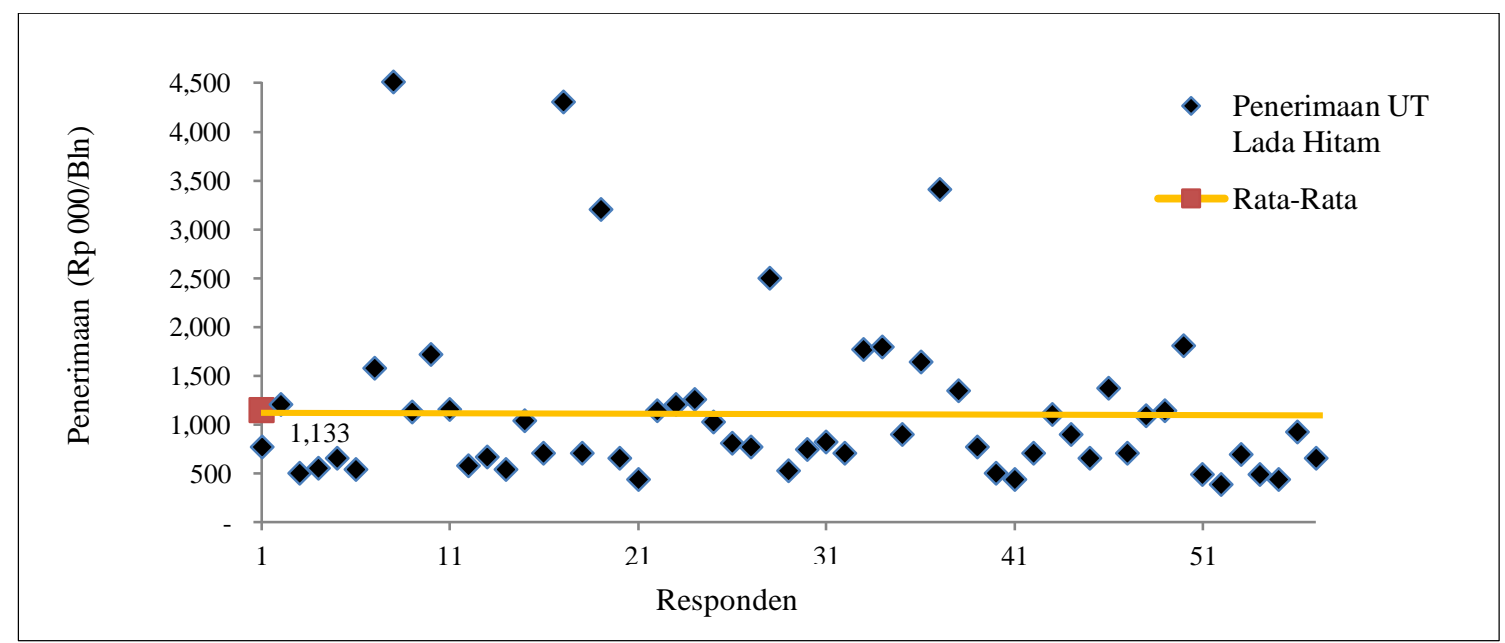

Gambar 2. Sebaran Penerimaan Usahatani Lada Hitam

Luas lahan usahatani lada hitam di Desa Temdak berkisar antara 0,25-3,50 Ha dengan rata-rata 1,27 Ha. Sebagian besar petani $(66,67 \%)$ memiliki lahan dengan kisaran 0,25-1,25 Ha. Luas lahan yang relatif sama ini yang antara lain menyebabkan penerimaan antar rumahtangga petani pun relatif merata. 
Status kepemilikan lahan juga seragam, yakni lahan milik sendiri.

Menurut Pratiwi dan Rondhi (2018) lahan pertanian merupakan aset yang berharga bagi petani sehingga akan mempengaruhi pendapatan petani. Perubahan distribusi kepemilikan lahan pertanian yang mengarah ke ketimpangan akan mempengaruhi pendapatan petani, demikian pula sebaliknya. Hal ini juga sejalan dengan pendapat Gurning dkk (2015), dimana pada masyarakat yang homogen seperti petani yang seluruhnya bermata pencaharian pokok sebagai petani dengan komoditi yang sama serta dengan pola pengelolaan yang sama, maka tidak ada perbedaan pendapatan di antara petani. Penerimaan Usahatani Non Lada Hitam Sementara itu, distribusi penerimaan rumahtangga dari usahatani non lada hitam termasuk ke dalam kategori ketimpangan sedang, baik berdasarkan nilai GR yang sebesar 0,40 maupun menurut kriteria Bank Dunia dimana $40 \%$ kelompok rumahtangga berpenerimaan terendah yang menerima $15,22 \%$ dari total penerimaan seluruh rumahtangga. Sebaran data penerimaan usahatani lada hitam disajikan pada Gambar 3.

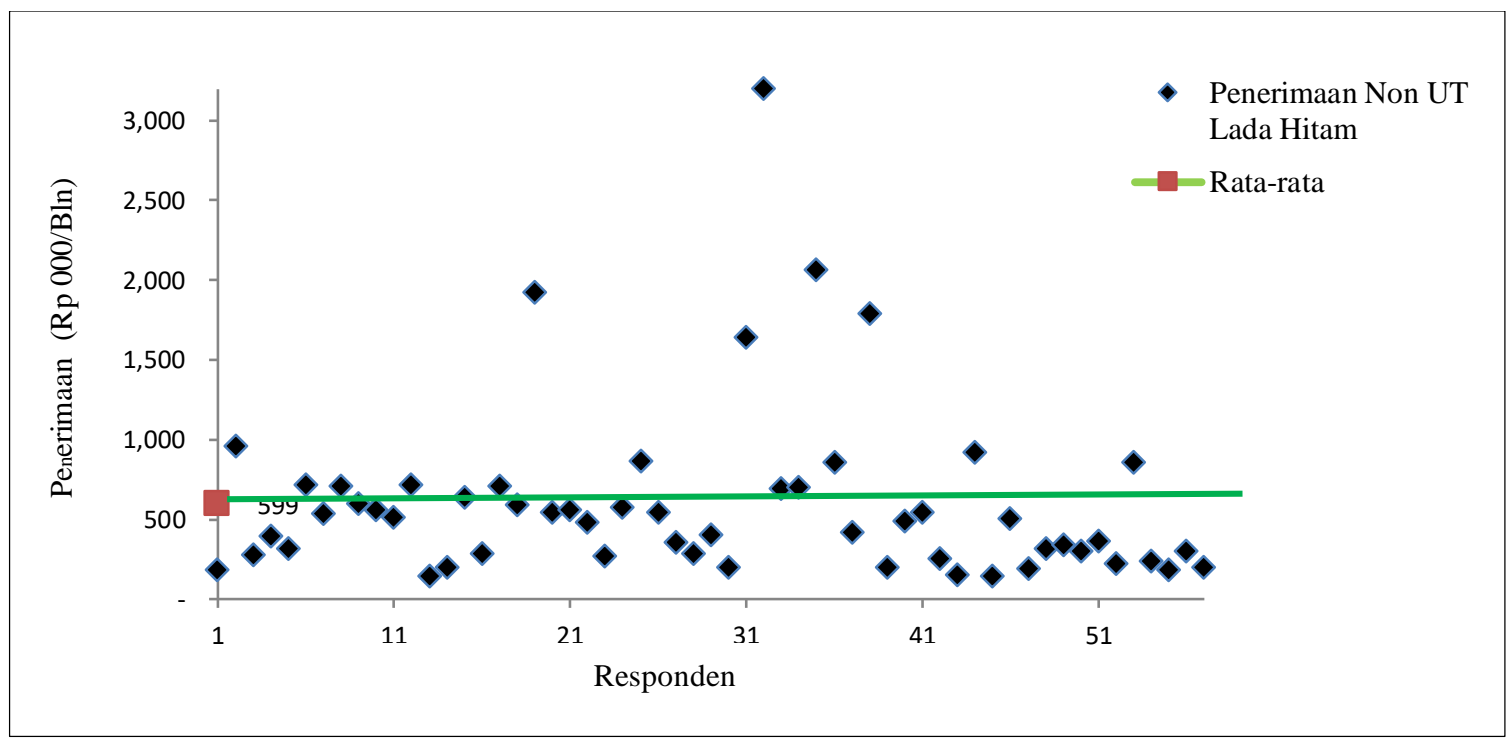

Gambar 3. Sebaran Penerimaan Usahatani Non Lada Hitam

Usahatani pertanian selain lada hitam yang dilakukan petani relatif beragam, yakni usahatani kopi, padi sawah, cabe, pala, kelapa sawit dan beternak kambing yang memberikan penerimaan yang bervariasi antara usahatani satu dengan lainnya. Peningkatan distribusi pendapatan 
disebabkan adanya diversifikasi dengan berbagai jenis komoditi yang beragam. Sumber penerimaan rumahtangga yang makin beragam menyebabkan ketimpangan semakin tinggi. Keberagaman sumber mata pencaharian ini dipengaruhi oleh kemampuan anggota rumahtangga untuk mengakses lapangan pekerjaan tersebut. Hal ini lah yang menyebabkan adanya perbedaan pendapatan yang diperoleh antar rumahtangga (Nasir dkk, 2015).

\section{Penerimaan Non Pertanian}

Distribusi penerimaan rumahtangga petani lada hitam yang berasal dari usaha non pertanian termasuk ke dalam kategori ketimpangan yang tinggi, dimana nilai GR yang diperoleh sebesar 0,70 dan menurut kriteria Bank Dunia persentase yang diterima oleh $40 \quad \%$ kelompok rumahtangga berpenerimaan terendah adalah sebesar $0,00 \%$. Sebaran data penerimaan non pertanian tampak pada Gambar 4.

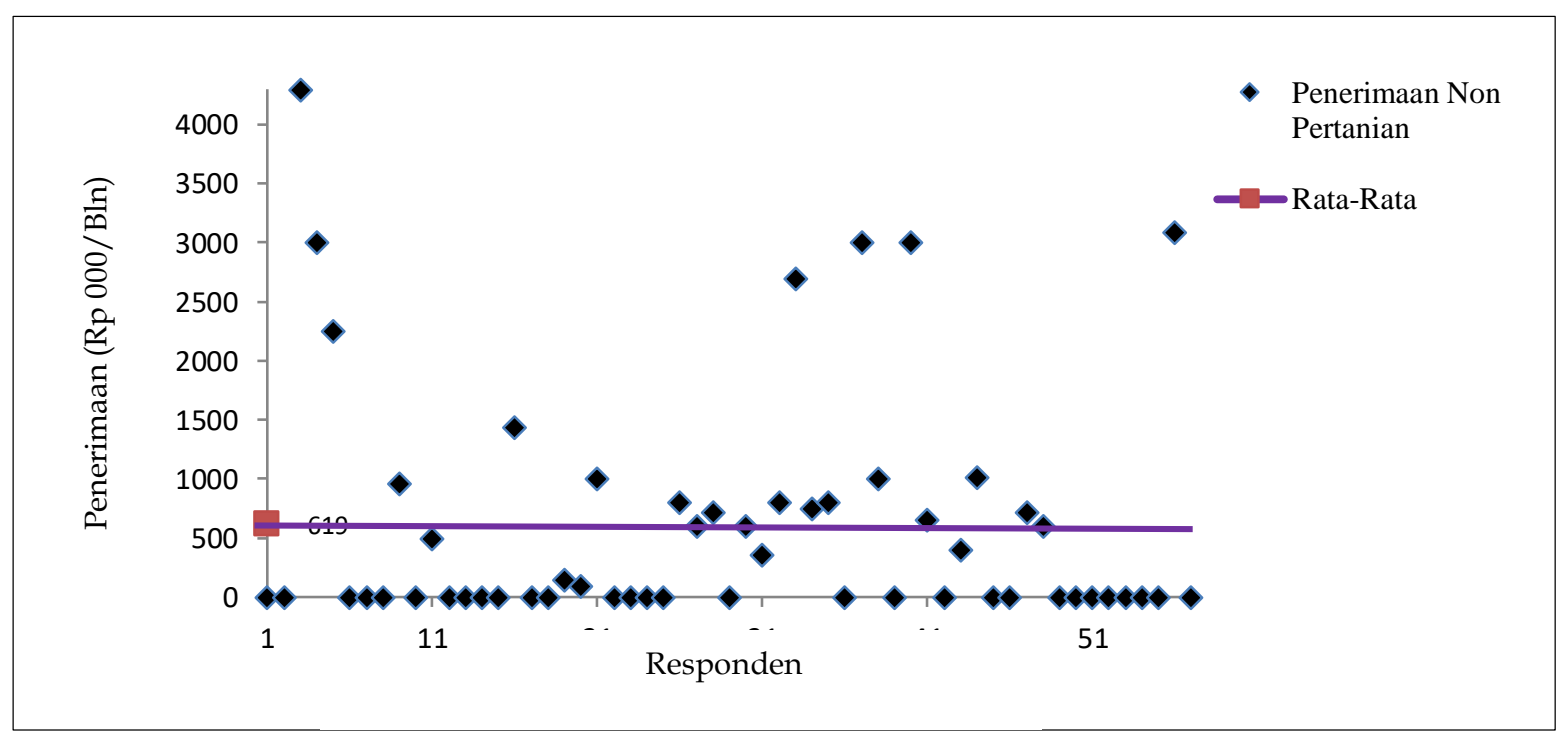

Gambar 4. Sebaran Penerimaan Non Pertanian

Ketimpangan distribusi penerimaan yang tinggi ini disebabkan oleh perbedaan akses yang dimiliki rumahtangga terhadap pekerjaan di luar sektor pertanian. Hanya sebagian kecil rumahtangga yang memiliki penerimaan yang sangat tinggi dari luar sektor pertanian. Sebagian besar rumahtangga petani tidak memiliki pekerjaan di luar sektor pertanian. sehingga penerimaan non pertaniannya tidak ada (nol). Perbedaan keterjangkauan terhadap pekerjaan di luar sektor pertanian ini disebabkan oleh perbedaan pendidikan dan keterampilan yang dimiliki. Hal ini 
didukung hasil penelitian Flachsbarth dkk (2018) yang menunjukkan bahwa pekerjaan non pertanian di perdesaan tidak berpihak kepada golongan miskin. Orang-orang yang mempunyai keterampilan yang lebih tinggi yang lebih diuntungkan. Primadhyta (2018) juga menyatakan bahwa penciptaan kesempatan kerja di pedesaan harus diiringi upaya peningkatan produktivitas pendudukan.

Hal ini didukung oleh Susilowati (2017) yang menyatakan bahwa peningkatan pendapatan rumahtangga petani melalui penciptaan keragaman sumber pendapatan rumahtangga membutuhkan peningkatan kapasitas sumber daya petani. Upaya yang dapat dilakukan adalah meningkatkan pendidikan dan keterampilan, sehingga setiap anggota masyarakat memiliki kesamaan akses atau keterjangkauan terhadap sumber pendapatan tersebut.

Menurut Mollers dan Buchenrieder (2011), lapangan pekerjaan luar sektor pertanian yang ada di perdesaan memiliki peran penting karena berpengaruh positif terhadap mata pencaharian masyarakat desa. Pengaruh tersebut melalui tiga cara, yakni sebagai sumber pendapatan paling penting dari usahatani kelas menengah, mengeluarkan rumahtangga miskin dari belitan kemiskinan, dan menjadi katalis untuk mengurangi ketimpangan ekonomi di wilayah perdesaan. Hasil penelitian AlAmin dan Hossain (2019) juga menunjukkan bahwa pendapatan nonpertanian meningkatkan ketimpangan pendapatan antar rumahtangga di perdesaam.

Sugiyarto dkk (2015) menyatakan juga bahwa kesempatan untuk mendapatkan pekerjaan di luar sektor pertanian dipengaruhi oleh tingkat pendidikan petani. Tingkat pendidikan yang rendah mengakibatkan pola pikir yang terbatas. Hal ini menyebabkan kurangnya akses atau keterjangkuan terhadap sumber-sumber penerimaan non pertanian.

Menurut Himanshu dkk (2013) sektor non pertanian pedesaan menampilkan heterogenitas yang sangat besar, dalam hal sektor maupun jenis pekerjaan. Kegiatan non pertanian secara umum dapat dibagi menjadi tiga subsektor yang mewakili berbagai jenis pekerjaan, yaitu : Pertama, pekerjaan reguler dengan penerimaan berupa gaji dimana pekerja memiliki waktu yang lama. Kedua, pekerjaan kontrak yang tidak memerlukan pembaruan harian, mingguan, atau bulanan dan upah buruh biasa yang membutuhkan pembaruan kontrak kerja harian atau berkala. Ketiga, wirausaha, di mana 
pekerja mengoperasikan sendiri pekerjaan atau usahanya. Sehingga sangat dimungkinkan terjadi ketimpangan penerimaan dari sektor non pertanian.

\section{Total Penerimaan Rumahtangga}

Penerimaan total rumahtangga petani menyebar relatif merata atau memiliki ketimpangan rendah. Hal ini ditunjukkan oleh nilai GR sebesar 0,35 (Tabel 4) dan persentase yang diterima oleh $40 \%$ kelompok rumahtangga berpenerimaan terendah sebesar 18,04 (Tabel 5). Gambar 5 juga menunjukkan hal yang demikian.

Jika dibandingkan dengan data BPS, pada bulan Maret 2019 nilai GR untuk wilayah perdesaan di Indonesia adalah sebesar 0,317. pada bulan September 2018 masih. Sementara untuk kriteria Bank Dunia sebesar 20,59 persen. Kedua angka ini menunjukkan bahwa ketimpangan ekonomi masyarakat di perdesaan termasuk kategori ketimpangan rendah (http://bps.go.id, 2019). Sebelumnya, yakni pada bulan September 2018, angka GR wilayah perdesaan sebesar 0,319 yang juga menujukkan bahwa distribusi ekonomi di perdesaan tergolong merata (Kementerian Pertanian Republik Indonesia, 2020).

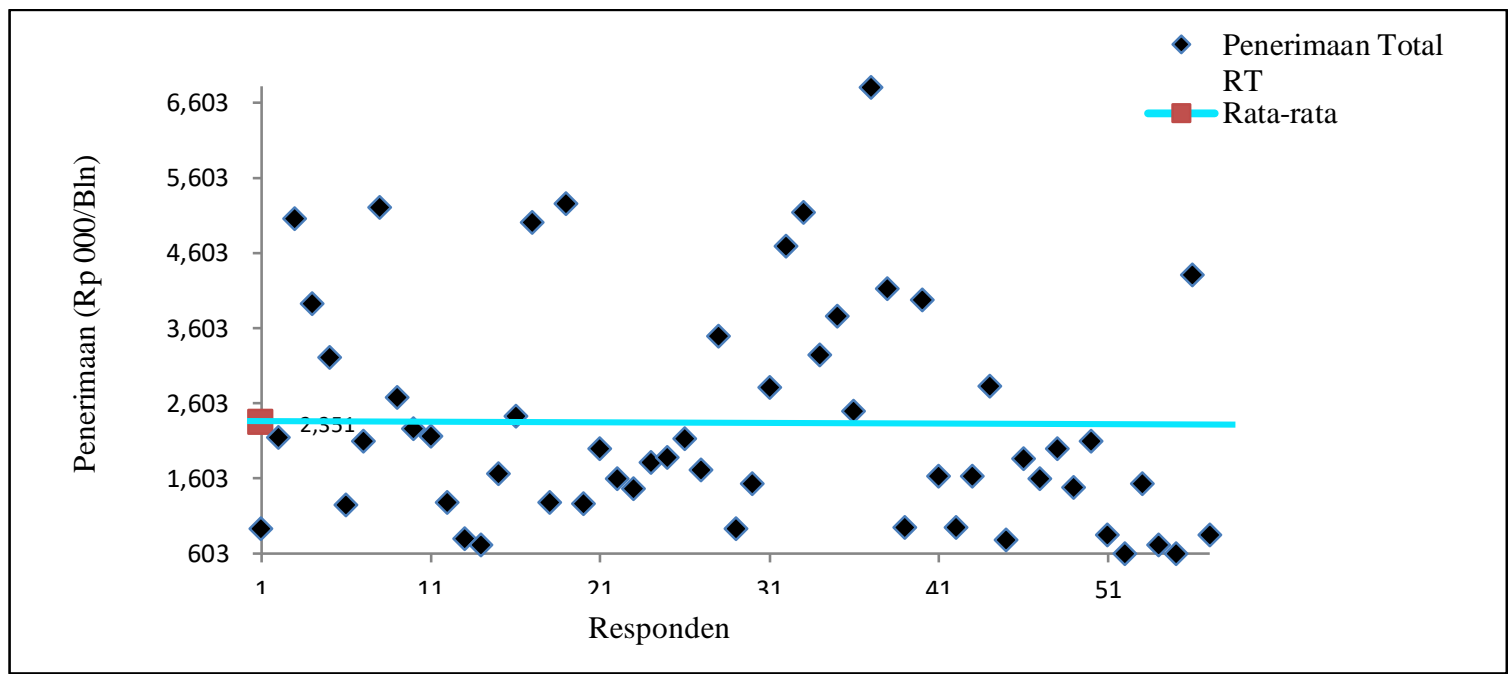

Gambar 5. Sebaran Total Penerimaan Rumahtangga

Seluruh petani lada hitam penerimaan rumahtangga berasal dari mengandalkan usahatani lada hitam usahatani lada hitam. Penerimaan dari sebagai sumber pemenuhan kebutuhan usahatani lada hitam relatif merata. rumahtangga, yakni hampir 50\% Selebihnya berasal dari usahatani non lada Jurnal AGRIBIS Vol XIII. No. 2 Juli 2020 Hal 1514-1528 
hitam dan non pertanian dengan persentase relatif kecil, sehingga distribusi penerimaan total rumahtangga relatif merata. Penjelasan lain yang dapat ditambahkan adalah bahwa menurut Adil dkk (2016) pendapatan rumahtangga petani komoditi perkebunan, dalam hal ini sawit, terdistribusi lebih merata. Hanya ada beberapa rumahtangga petani yang memiliki pendapatan lebih tinggi karena memiliki lahan yang lebih luas serta memiliki pendapatan sampingan di sektor pertanian lainnya maupun dari sektor non pertanian.

\section{KESIMPULAN}

Kesimpulan dari hasil penelitian ini adalah tingkat ketimpangan distribusi penerimaan rumahtangga petani lada hitam di Desa Temdak berdasarkan Gini Ratio dan kriteria Bank Dunia menunjukkan hasil yang senada. Penerimaan usahatani lada hitam dan total penerimaan rumahtangga terkategori ketimpangan rendah dengan nilai GR masing-masing 0,351 dan 0,350 serta berdasarkan kriteria Bank Dunia masing-masing 19,26\% dan $18,04 \%$. Penerimaan usahatani non lada hitam termasuk dalam kategori ketimpangan sedang dengan nilai GR sebesar 0,398 dan 15,22\% menurut kriteria Bank Dunia. Sementara ketimpangan penerimaan non pertanian antar rumahtangga petani lada hitam tergolong ketimpangan tinggi yang ditunjukkan oleh nilai GR 0,705 dan 0,00\% berdasarkan kriteria Bank Dunia.

\section{DAFTAR PUSTAKA}

Adil, Posma, Eliza dan Suardi Tarumun. 2016. Distribusi Pendapatan Petani Kelapa Sawit Polaswadaya di Desa Rimpian Kecamatan Lubuk Batu Jayakabupaten Indragiri Hulu. JOM Faperta Universitas Riau 3 (2) : $1-9$.

Al-Amin, A.K.M. Abdullah dan M.J. Hossain. 2019. Impact of Nonfarm Income on Welfare in Rural Bangladesh: Multilevel Mixedeffects Regression Approach. World Development Perspectives $13: 95-102$.

Flaschbarth, Insa, Simone Schotte, Jann Lay dan Alberto Garrido. 2018. Rural Structural Change, Poverty and Income Distribution: Evidence from Peru. The Journal of Economic Inequality 16:631-53.

Gurning, Elista K., Yusmini dan Susy Edwina. 2015. Struktur dan Distribusi Pendapatan Rumahtangga Petani Kelapa Sawit Pola Swadaya Desa Kota Tengah Kecamatan Dolok Masihul Kabupaten Serdang Bedagai Sumatera Utara. Jom Faperta 2 (2).

Himanshu, Peter Lanjouw, Rinku Murgai dan Nicholas Stern. 2013. NonFarm Diversification, Poverty, Economic Mobility and Income Inequality : A Case Study in Village India. Policy Research 
Working Paper. The World Bank Development Research Group Poverty and Inequality Team. https://papers.ssrn.com. Diakses Tanggal 21 Januari 2019 Pukul 18.00 WIB.

http://bps.go.id. 2019. Berita Resmi Statistik : Gini Ratio Maret 2019 Tercatat Sebesar 0,382.

https://kepahiang.progres.id. 2016. Seberang Musi Diproyeksi Jadi Sentra Lada Terbesar di Provinsi Bengkulu.

Kementerian PPN/Bappenas Republik Indonesia. 2017. Siaran Pers : Membedah Angka Kemiskinan dan Kesenjangan: Rilis Data Terkini BPS. https://www.bappenas.go.id. Diakses Tanggal 12 November 2017 Pukul 16.35 WIB.

Kementerian Pertanian Republik Indonesia. 2020. Tahun Ini, Ketimpangan Pendapatan Semakin Turun.

https://www.pertanian.go.id.

Diakses Tanggal 22 April 2020 Pukul 16.35 WIB.

Kuncoro, Mudrajad. 1997. Ekonomi Pembangunan: Teori, Masalah dan Kebijakan. Edisi Ketiga. UPP AMP YKPN. Yogyakarta.

Lithourgidis, A.S. C.A. Dordas, C.A. Damalas, dan D.N. Vlachostergios. 2011. Annual Intercrops: An Alternative Pathway for Sustainable Agriculture. Australian Journal of Crop Science (AJCS) 5 (4) : 396-410.

Mollers, Judith dan Gertrud Buchenrieder. 2011. Effects of Rural Non-farm Employment on Household Welfare and Income Distribution of Small Farms in Croatia. Quarterly
Journal of International Agriculture 50 (3) : 217-235.

Nasir, Imran Zahri, Andi Mulyana dan Yunita. 2015. Analisis Struktur dan Distribusi Pendapatan Rumahtangga Petani di Lahan Rawa Lebak. Agrisep 14 (1) : 97107.

Pratiwi, Pravitasari Anjar dan Mohammad Rondhi. 2018. Distribusi Kepemilikan Lahan Pertanian dan Pendapatan Usahatani di Wilayah Perkotaan Kabupaten Jember. SEPA 15 (1) : 80-90.

Primadhyta, Safyra. 2018. Indonesia dan Jurang Ketimpangan yang 'Menganga'.

https://www.cnnindonesia.com.

Diakses Tanggal 22 April 2020 Pukul 17.20 WIB.

Risfaheri. 2012. Diversifikasi Produk Lada (Piper nigrum L) untuk Peningkatan Nilai Tambah. Buletin Teknologi Pascapanen Pertanian Badan Litbang Pertanian Kementrian Pertanian Indonesia 8 (1) : 15-25.

Sa'diyah, Siti Halimatus dan Irham. 2016. Peran Sektor Pertanian dalam Mengurangi Ketimpangan Pendapatan di Wilayah Papua Sebelum dan Sesudah Otonomi Khusus. Agro Ekonomi 27 (1) : 1 -18 .

Susilowati, Sri Hery. 2017. Dinamika Diversifikasi Sumber Pendapatan Rumahtangga Perdesaan di Berbagai Agroekosistem. Jurnal Agro Ekonomi 35 (2) : 105-126.

Sugiyarto, Jangkung Handoyo Mulyo dan Rosalia Natalia Seleky. 2015. Kemiskinan dan Ketimpangan Pendapatan Rumahtangga di 
Kabupaten Bojonegoro. Jurnal Agro Ekonomi 26 (2) : 115-120.

Todaro, Michael P. dan C.S. Smith. 2003. Pembangunan Ekonomi di Dunia Ketiga. Edisi Kedelapan. Erlangga. Jakarta.

Yasrizal dan Ishak Hasan. 2016. Pengaruh Pembangunan Sektor Pertanian terhadap Distribusi Pendapatan dan Kesempatankerja Di Indonesia. JIEP 16 (1) : 54 64. 